\title{
Chinese in the Australian Dictionary of Biography and in Australia ${ }^{1}$
}

TIPING SU

\section{Chinese people and other ethnic groups in the Australian Dictionary of Biography}

According to Tom Griffiths, chairman of the editorial board of the Australian Dictionary of Biography $(A D B)$, the dictionary is 'the largest and most successful cooperative research enterprise in the humanities and social sciences in Australia', which captures the life and times and culture of this country in an absolutely distinctive and irreplaceable way'. ${ }^{2}$ Since the first volume was launched in 1966 , more than 4,500 authors have contributed just over 13,000 entries. The general editor, Melanie Nolan, has observed that 'the dictionary has survived the test of time, providing material for others to construct their own images of the "real" Australian or the "typical Australian"'. 3 To reflect this 'real Australian' ethos, the $A D B$ records the cultural heritage (ethnicity) of subjects. Of the top 10 ethnicities in Australia, as recorded by the Australian Bureau of Statistics, a search on the $A D B$ website (adb.anu.edu.au) found that, as of September 2018, 6,624 subjects were of British heritage (4,841 English, 1,624 Scottish, 159 Welsh), 294 were from New Zealand, 32 were Chinese, 10 were Indian, none were of Philippine or Vietnamese heritage, 88 were Italian, 29 were South African, two were Malayan and 321 were German. ${ }^{4}$ Thus, people of Asian heritage are clearly under-represented. To illustrate the significance of this omission, or neglect, I will take the Chinese entries as an analytic group, and suggest where improvements could be made. The Chinese are of particular importance because they were the largest non-European group in the Australian population in the nineteenth century.

\footnotetext{
1 This paper was sponsored by a grant from the Key Program of Education Department of Shaanxi Provincial Government, China 'Evolution of Ethnic Identity and National Identity in Australian Aboriginal Literature' (Program No. 17JZ061). I want to express my sincere gratitude to Melanie Nolan and Malcolm Allbrook for their suggestions on this paper and their help during my visit to ANU. I also want to thank the referees for their detailed comments, revisions and suggestions.

2 Tom Griffiths, 'Foreword', in The ADB's Story, ed. Melanie Nolan and Christine Fernon (Canberra: ANU E Press, 2013), xi.

3 Melanie Nolan, “'Insufficiently Engineered”: A Dictionary Designed to Stand the Test of Time?', in Nolan and Fernon, The ADB's Story, 22.

4 Australian Bureau of Statistics, 3412.0-Migration, Australia, 2013-14. ESTIMATED RESIDENT POPULATION, Australia-Top 10 countries of birth-30 June 2014, accessed 2 August 2016, www.abs.gov.au/ AUSSTATS/abs@.nsf/allprimarymainfeatures/41C0506CD4276A2CCA257F8500171C5E?opendocument.
} 
The 32 Chinese are represented in 13 volumes and the $A D B$ online (one in Volumes 6, 9 and 14; two in Volumes 3, 7, 11, 12, 13 and 17; three in Volumes 5 and 16, and the 2005 supplementary volume; and five in Volume 18). Three further biographies have been published online and will appear in Volume 19. Of these 32 people, 10 were born outside China, eight in Australia, one in Malaysia and one in Papua New Guinea. They worked in diverse areas: Lowe Kong Meng and William Joseph Liu were merchants; Lester Leon and Rose Maud Quong were artists; Shen and Lee were restauranteurs; William Ah Ket was a barrister; Caleb James Shang was a herbalist; Harry Chan was a politician; Hoi Meen Chin was a photographer;Samuel John Tong-Way was a teacher; and Chang was a surgeon. All had been to school and four proceeded to obtain degrees.

Seventeen of the China-born Chinese came from Guangdong province, the others coming from Shanghai (Egge, Chang), Shandong (Bing Guin Lee), Jiangsu (Kiangsu) (Wang) and Beijing (Shen). Almost all were merchants except two missionaries (Cheong Cheok Hong and Ten), one market gardener (Kong Shuen Lau), one riverboat captain (Egge) and one cardiac surgeon (Victor Peter Chang). Fourteen had gone to school at least for several years, and some went on to college (Cheong Cheok Hong and Wang), while Victor Chang obtained a PhD after arriving in Sydney in 1951. Although the biographies do not mention the educational qualifications of the remaining six people, they were all able to speak English.

From this we can see that 80 per cent of the Chinese subjects in the $A D B$ went to school, and all of them spoke some English, which shows that education or involvement with the local community was a factor in their significance to Australia; nearly two-thirds were merchants; and Guangdong was the main place of origin of many of the Australian Chinese. To some extent, these people came to represent the Chinese in Australia, but there are others who were neglected or under-represented; for example, those who participated in the gold rushes, of whom only one (Ah Mouy) appears in the $A D B$.

\section{The 'missing' people}

It is hard to be precise about the first Chinese person to arrive in Australia, although it is believed to have been Mak Sai Ying, or Mak O’Pong, who arrived in Sydney on 27 February 1818 on the Laurel, an Indian-built vessel, possibly a part of the East India Company fleet. ${ }^{5}$ Some believe that the first recorded Chinese-born settler was a carpenter, Ahuto, who came to Australia as a free man in 1803, rather than Mak Sai Ying, who may not have been born in China. Some Chinese-born people

5 'Mak Sai Ying Aka John Shying', Parramatta Heritage Centre, City of Parramata Council, 27 January 2018, accessed 24 April 2017, arc.parracity.nsw.gov.au/blog/2017/01/27/mak-sai-ying-aka-john-shying/. The date of his birth is not confirmed yet. According to the Parramatta Heritage Centre, he was born in 1798 . 
may have arrived in Australia much earlier, but no extant document shows this. James Donohoe suggested that 'the Chinese were regular visitors to North Australia from the eleventh to the fourteenth century where they gathered beche-de-mer, or sea cucumber, which was a known delicacy' ${ }^{6}$

Few documents about the Chinese in Australia were written before the gold rush, but one man, Louis Ah Mouy (1826-1918), changed this. 'His arrival', wrote Ching Fatt Yong in Volume 3 of the $A D B$ :

Coincided with the discovery of gold in Victoria. He broke the news to his brother at Canton and his letter was said to have prompted the migration of many thousands of Cantonese to the Victorian goldfields in the 1850s. ${ }^{7}$

According to Australian official data, there were 2,341 Chinese people living in Victoria in 1854 and the number expanded rapidly to 24,732 in $1861 .^{8}$ In the meantime, Chinese people arrived in other Australian colonies. For example, 8,000 left Victoria following the imposition of punitive taxes and immigration restrictions there and in South Australia. In 1861 the number in New South Wales had risen to nearly 13,000, with over 38,000 Chinese people in Australia altogether. This is the peak of Chinese immigration to Australia during the first 100 years of European settlement, although official data may understate the actual numbers; some estimated there were more than 200,000 in the 1870 s, which cannot be verified. Chinese official data shows that approximately 55,000 people left for Australia between 1851 and $1875,{ }^{9}$ and almost all these people came for gold. After the gold rush some of them settled down and became permanent residents, although there were not many new immigrants added (Table 1).

Thus during Australia's first 100 years, the population of Chinese was quantitatively and proportionally small. The year 1861 witnessed a peak, when the proportion of Chinese-born in the Australian population was 3.3 per cent (see Table 1). The overwhelming majority of these immigrants were men who came without their wives, so that:

The Chinese in Australia had a staggering sexual imbalance. In 1861 Victoria had 8 females out of a total Chinese population of 24,732 and New South Wales had 2 in a total of $12,988 . .^{10}$

6 James Hugh Donohoe, The Forgotten Australians: The Non Anglo or Celtic Convicts and Exiles (North Sydney: J.H. Donohue, 1991), 51.

7 Yong Ching Fatt, 'Ah Mouy, Louis (1826-1918)', Australian Dictionary of Biography (Melbourne: Melbourne University Press, 1969), 3:19-20.

8 刘渭本. 澳洲华侨史. 台北：星岛出版社，1989: 28 [Weiping Liu, Overseas Chinese History of Australia (Taipei: Singtao Books, 1989), 28].

9 Liu, Overseas Chinese History of Australia, 28.

10 Jupp, The Australian People, 79. 
There was thus little prospect of a significant second generation, as shown in Table 2. Although data on the second generation after 1921 has not been obtained, the diminishing numbers of first generation Chinese augured a slow growth of the second generation. However, among these second generation there do appear to be some eminent figures, like Billy Sing.

Table 1: Chinese living in Australia 1854-1947.

\begin{tabular}{|r|r|r|r|r|r|r|r|r|r|r|}
\hline Year & Vic. & NSW & QId & SA & WA & Tas. & NT & $\begin{array}{r}\text { Total } \\
\text { Chinese } \\
\text { population }\end{array}$ & $\begin{array}{c}\text { Total } \\
\text { Australian } \\
\text { population }\end{array}$ & $\%$ \\
\hline 1854 & 2,341 & & & & & & & 2,341 & & \\
\hline 1856 & & 1,806 & & & & & & 1,806 & & \\
\hline 1857 & 25,424 & & & & & & & 25,424 & & \\
\hline 1861 & 24,732 & 12,988 & 538 & 40 & 20 & 30 & & 38,348 & & 3.3 \\
\hline 1871 & 17,935 & 7,220 & 3,305 & & & & & 28,460 & & 1.7 \\
\hline 1881 & 12,128 & 10,205 & 11,229 & 4,151 & 145 & 844 & & 38,702 & $2,250,194$ & 1.7 \\
\hline 1891 & 8,489 & 13,157 & 8,524 & 182 & 917 & 939 & 3,613 & 35,821 & $3,174,392$ & 1.1 \\
\hline 1901 & 6,247 & 10,222 & 7,672 & 287 & 1,521 & 506 & 3,072 & 29,527 & $3,773,801$ & 0.78 \\
\hline 1911 & 4,707 & 8,226 & 5,995 & 255 & 1,812 & 427 & 1,331 & 22,753 & $4,455,005$ & 0.51 \\
\hline 1921 & 2,825 & 6,617 & 3,585 & 254 & 1,226 & 235 & 475 & 15,224 & $5,435,734$ & 0.28 \\
\hline 1933 & 1,690 & 3,398 & 1,705 & 89 & 672 & 104 & 129 & 7,792 & $6,629,839$ & 0.12 \\
\hline 1947 & 1,112 & 2,529 & 656 & 137 & 310 & 54 & 59 & 4,858 & $7,579,358$ & 0.06 \\
\hline
\end{tabular}

Note: Data on Chinese populations for 1921 from Australian Census records differ from that published in Liu, Overseas Chinese History of Australia, 30-38.

Sources: Australian Bureau of Statistics. Australian population totals 1881-1911 from Census of the Commonwealth of Australia, Vol. III, 1911, 2055; data for 1861-91 excluding the total Australian population from James Jupp, The Australian People: An Encyclopedia of the Nation, Its People and Their Origins (North Ryde, NSW: Angus \& Robertson Publishers, 1988), 299; data for 1854, 1856, 1857, 1901 and 1911 are from Liu, Overseas Chinese History of Australia, 30-38; data for 1921 from Census of the Commonwealth of Australia, Vol. 1, 1921, 49; data for 1933 from Census of the Commonwealth of Australia, Vol. 1, 1933, 844; data for 1947 from Census of the Commonwealth of Australia, Vol. 1, 1947, 786-87.

Table 2: The second generation of Chinese in Australia, 1881-1921.

\begin{tabular}{|l|r|r|r|r|r|r|r|r|}
\hline Year & \multicolumn{1}{|c|}{ Vic. } & \multicolumn{1}{c|}{ NSW } & \multicolumn{1}{c|}{ Qld } & \multicolumn{1}{c|}{ SA } & WA & Tas. & NT & \multicolumn{1}{c|}{ Total } \\
\hline 1881 & 169 & & & & & & & 169 \\
\hline 1891 & 888 & 867 & 50 & 5 & & 117 & 91 & 2,018 \\
\hline 1901 & 1,002 & 1,041 & 800 & 48 & 48 & 103 & 48 & 3,090 \\
\hline 1911 & 892 & 1,132 & 719 & 104 & 60 & 102 & 8 & 3,017 \\
\hline 1921 & 1,017 & 1,394 & 957 & 116 & 118 & 59 & 8 & 3,669 \\
\hline
\end{tabular}

Source: Liu, Overseas Chinese History of Australia, 30-38. 
In proportional terms, only 0.24 per cent of the entries in the $A D B$ are Chinese people. In their various professions, regions of origin and educational backgrounds, the Chinese in the $A D B$ also demonstrate the diversity of Chinese overseas experience, just as contemporary studies in the areas of history and ethnography show. ${ }^{11}$ At the same time, as studies of the nineteenth and early twentieth centuries show, 'overseas Chinese communities have been portrayed as conservative and homogenous collectives'. ${ }^{12}$ To some extent, this stereotype has been reflected in the $A D B$. Only one goldminer (Ah Mouy, 1826-1918) appears, although 'at its peak in 1858 the Chinese population of the Victorian goldfields number[ed] 33,673 of a total population of $171,647^{\prime} \cdot{ }^{13}$ This may suggest a poor understanding of the complexity of Chinese communities and 'the shifting, fluid character of Chineseness' ${ }^{14}$

A number of historical factors might have contributed to the Chinese being a neglected or 'missing' people in the annals of the $A D B$. Firstly, the vast majority of the gold-seekers were poorly educated. The gold rushes in 1850s Australia attracted thousands of Chinese gold-seekers from Canton (Guangzhou) and surrounding counties. According to the Report of the Select Committee of the Legislative Council on Chinese Immigration of 1857, two-thirds of Chinese immigrants to Victoria were said to be farmers with no property, and the other third were artisans, shopkeepers and merchants. Most of them were less educated, partly because of the rural economy and partly because of their geographical isolation from cultural centres, ${ }^{15}$ so they left few written documents about themselves and their lives in Australia. Furthermore, they had few social connections with other communities, and were even isolated from other Chinese communities of different dialects. To complicate matters further, many were considered in China to be an underclass who had abandoned their homelands, and hence were deemed pariahs with no records in the official documents of their country. ${ }^{16}$

Secondly, most of the overseas Chinese in Australia tended to isolate themselves from the outside world. Most came to Australia with a common ideal and desireto return to the Flowery Land where their ancestors were buried and to retire there. ${ }^{17}$ They may be classified more as 'sojourners' than settler immigrants, retaining connections with the home environment, sending remittances when they could and, in general, working towards the day when they could return. Thus they tended

11 Kevin Rains, 'Webs of Association: Examining the Overseas Chinese Social Landscape of Early Cooktown', Chinese Southern Diaspora Studies [南方华裔硏究杂志] 6 (2013): 25-44.

12 Rains, 'Webs of Association', 25.

13 Jupp, The Australian People, 79.

14 Jane Lydon, Many Inventions: The Chinese in the Rocks, Sydney 1890-1930 (Clayton, Vic.: Monash University Press, 1999), 13.

15 C. F. Yong, The New Gold Mountain: The Chinese in Australia, 1901-1921 (Richmond, SA: Raphael Arts, 1977), 1.

16 Liu, Overseas Chinese History of Australia, 72.

17 Yong, The New Gold Mountain, 2-3. 
not to involve themselves deeply in the local society, preferring instead to maintain, where they could, family or kinship networks. The presence of kinsmen was vital for the maintenance of social environments that not only provided security and mutual support, but also maintained the values and practices linking sojourners with their families at home. ${ }^{18}$ Although the Chinese and Europeans were interdependent for particular commodities and services, the Chinese sojourners may also have aspired to maintain formal distance and independence, and their relations with the Europeans remained short-term and utilitarian. Therefore, these people had little social power within the European colonial system and their connections with the wider world were superficial and minimal, ${ }^{19}$ so they were not recorded in Australian official documents.

Thirdly, racial barriers prevented the Chinese immigrants from becoming involved in colonial Australian society. Visible contrasts, such as language, clothes, hairstyle, habits, customs, traditions and modes of life maintained the gap between Chinese and the European majority and ensured that they remained 'foreign'. In addition, episodes of racial violence on the goldfields deepened Australian hostility to the Chinese sojourners:

An objection to the different Chinese value system, a fear of being overrun by the vast population of China and the perceived failure of Chinese immigrants to assimilate with white society. ${ }^{20}$

Thus 'except for business contacts, there was negligible social and cultural intercourse between these two races which represented two different cultures-the Oriental and the Occidental'. ${ }^{21}$

Of course, the overseas Chinese experience was diverse and some became actively involved in local society and had rich interactions with Europeans; most of those in the $A D B$ fall into such a category. Even in such business contacts, Europeans who dealt with Chinese businesses could turn against them to pursue their own interests. Under these circumstances, some Chinese chose the path of assimilation and largely abandoned their ethnic identity. For instance, Jimmy Ah Foo, from Cooktown, died in 1916 in the care of his westernised family and was given a Christian burial in the Protestant section of the Longreach cemetery. ${ }^{22}$ For these reasons, the overwhelming majority of overseas Chinese in Australia became 'missing' people; but there are still those who escaped the net of history and became visible.

18 Rains, 'Webs of Association', 30.

19 Rains, 'Webs of Association', 25-36.

20 Rains, 'Webs of Association', 29.

21 Yong, The New Gold Mountain, 5.

22 Rains, 'Webs of Association', 36. 


\section{Who could be added to the $A D B$ ?}

The arrival of indentured Chinese labourers into Australia may date back to 1848, the Sydney Morning Herald reporting the arrival of 120 Chinese labourers from Hong Kong on 6 June 1848. Others arrived on 7 July, while another group landed in Australia on 2 October $1848 .{ }^{23}$ Among the gold-seekers arriving after 1851 from Canton (Guangzhou) and surrounding counties, two-thirds were indentured labourers. ${ }^{24}$ Chen Ah Kew, as Barry McGowan relates in Tracking the Dragon (2015), was one of them..$^{25}$ According to his family members, he came to Australia at age 17, landed at Robe in South Australia, and trekked 500 kilometres to the Victoria goldfields, thereby avoiding the Victoria poll tax. He spent most of his life in Australia and became economically successful, developing 'contacts and friendships at the highest levels in white Australia', before he took his family back to his hometown in 1901 and died shortly afterwards in $1902 .{ }^{26}$ Later, his offspring emigrated to Melbourne one after another.

However, the vast majority of indentured labourers are hard to trace, as with most of the goldminers. They were seen as part of an amorphous mass and not recognised as individuals until much later, when some became prominent citizens in their own communities, such as Chen Ah Kew. The indentured labourer is one of the significant missing categories in the $A D B$. Apart from gold-seekers, there were many other missing people-Sun Johnson (孙俊臣), for instance. He was the co-founder and editor of the first Chinese-language newspaper in Sydney, The Chinese Australian Herald (廣縊華報 [Guangyihuabao]) (1894-1923), the title meaning 'paper for extending benefits to the public'. ${ }^{27}$ Born in either 1865 or 1868 , he was educated in Hong Kong and then London before migrating to Sydney in the late 1880s. He wrote and published a book under the title Chinese English Self-Educator in 1891, and was involved in both the European and Chinese communities, achieving a wealth of cross-cultural experience, which in turn equipped him to be one of the bilingual leaders of the Chinese community. ${ }^{28}$

23 Sydney Morning Herald, 3 October 1848, 2, accessed 23 October 2016, trove.nla.gov.au/newspaper/article/ 12910790 .

24 Yong, The New Gold Mountain, 1.

25 Barry McGowan, Tracking the Dragon: A Study of the Chinese in the Narrandera District of New South Wales (Wagga Wagga, NSW: Museum of the Riverina, 2015), 5.

26 McGowan, Tracking the Dragon, 108-9.

27 'Chinese-Language Australian Newspapers', Chinese-Australian Historical Images in Australia, Chinese Museum, accessed 23 October 2016, www.chia.chinesemuseum.com.au/biogs/CH00047b.htm.

28 Mei-fen Kuo, 'Modern "Imagined” Chinese Community in 1890s Colonial Sydney', Chinese Southern Diaspora Studies 2 (2008): 38-39. 
The idea of a 'white Australia' has a history of more than 100 years and can be traced at least to 1841, when an immigration committee believed that 'coolie immigration would lower the living standards of white men'. ${ }^{29}$ The gold rush in the 1850s consolidated the foundations of this idea on the grounds that 'the influx of Chinese diggers caused alarm, fear, mistrust, and misunderstanding ${ }^{30}$ among Europeans and 'a comparative handful of colonists may be buried in a countless throng of Chinaman'. ${ }^{31}$ Therefore, 'hostility to the Chinese, manifested in petitions and at public meetings, was also demonstrated more directly. ${ }^{32}$ In order to make a living and ensure the acceptance (or at least escape ostracism) of oneself or one's family, many Chinese people would adopt a strategy of assimilation and abandon or conceal their past and traditions, and even social networks, including Anglicising their names and converting to Christianity, ${ }^{33}$ such as Jimmy Ah Foo (as mentioned above),,$^{34}$ 'Billy' Sing and others.

An obituary for William Edward 'Billy' Sing (1886-1943) was added to the online Obituaries Australia in 2016 but his Chinese heritage was not mentioned. In fact his father, John Sing (c. 1842-1921), came from Shanghai and worked as a drover, and his mother, Mary Ann, came from England as a nurse. He lived in a time of considerable anti-Chinese sentiment and became the subject of racial prejudice due to his ancestry, although his family lived a westernised life. ${ }^{35}$ Therefore, he had been forgotten for a long time until a statue was unveiled in his hometown of Proserpine, Queensland, in 1995. He is regarded as the most successful sniper in Australian army history, fighting at Gallipoli and the Western Front, and winning a DCM and a Belgian Croix de Guerre.

Some Chinese people stayed in Australia for a short time but exercised great influence among overseas Chinese, such as Wang Ronghe (Wong Yung Ho 王荣 和) ${ }^{36}$ and Liang Qichao (梁启超). Wang Ronghe, a general from Fujian Province, was delegated by the Viceroy of Liangguang (两广总督) and the central government of the Qing Dynasty to investigate overseas Chinese in South-East Asia and Australia. Arriving in Darwin in 1887, he travelled to Sydney, Melbourne, Adelaide and Brisbane, receiving a warm welcome from Chinese residents ${ }^{37}$ and Australian

\footnotetext{
29 Yong, The New Gold Mountain, 11.

30 Yong, The New Gold Mountain, 11.

31 Geoffrey Serle, The Golden Age: A History of the Colony of Victoria, 1851-1861 (Parkville, Victoria: Melbourne University Press, 1963), 334.

32 Andrew Markus, Fear and Hatred: Purifying Australia and California, 1850-1901 (Sydney: Hale \& Iremonger, 1979), 22.

33 Barry McGowan, 'From Fraternities to Families: The Evolution of Chinese Life in the Braidwood District of New South Wales (NSW), 1850s-1890s', Chinese Southern Diaspora Studies 2 (2008): 25-30.

34 K. J. Rains, Cedars of the West: The Ah Foo Family Story (Melbourne: Chinese Heritage in Northern Australia, 2011).

35 John Hamilton, Gallipoli Sniper: The Life of Billy Sing (Sydney: Pan Macmillan Australia, 2008), 19.

36 Sing-Wu Wang, 'Diplomatic Relations between China and Australia Prior to the Establishment of the Chinese Consulate in Melbourne in 1909', Chinese Culture (Taipei) 6, no. 2 (1969): 27-42.

37 'The Chinese Commissioners at the City Mission Hall', South Australian Advertiser, 25 June 1887, 6.
} 
colonial governments, until rumours began to circulate that his survey was a prelude to large-scale migration from China. He presented a detailed report about his survey to the Chinese Government, revealing for the first time the landscape of the overseas Chinese in Australia.

Liang Qichao (1873-1929), a chief leader of the ill-fated Hundred Days' Reform in 1898, was the first man of letters and scholarship to set foot in Australia when he arrived in Perth on 25 October 1900; he stayed for half a year to 'enlist financial and political support' for his reforms, that is, 'to compass the downfall of the Empress Dowager, secure the reinstatement of the Emperor and the establishment of a liberal and representative form of government' ${ }^{38} \mathrm{He}$ was well received by state governments and welcomed by the Chinese in Australia. 'His tour resulted directly or indirectly in the formation of ten branches of the Chinese Empire Reform Association in Australia and the collection of at least $£ 5,000$ from Chinese in this country. ${ }^{39}$ During this period, he composed 27 poems about his travels, many of which were published in the Tung Hua News (东华新报) and later were included in his Ice-Drinking Room Combined Collected Works (《饮冰室合集》) and an uncompleted monograph, 'Chinese History of the Latest Decade' (《中国近十年史论》).

The nineteenth century witnessed the humiliation and disasters of modern China after the Nanking Treaty of 1842. The Chinese Government and Emperor were busy with domestic and foreign challenges and had no time, willingness, or ability to worry about overseas Chinese. Under the circumstances, only two officials kept a watch on overseas Chinese in Australia: Zhang Zhidong and Xue Fucheng. Zhang Zhidong (1837-1909) submitted a memorial to the throne on 25 February 1886 to investigate overseas Chinese in South-East Asia and Australia when he held the post of viceroy of Liangguang, and appointed Wang Ronghe and Yu Qiong as commissioners. ${ }^{40}$ Based on Wang and Yu's report, he submitted another memorial on 24 October 1887, in which he recorded part of Wang's report about the Chinese in Australia and, unsuccessfully, suggested the establishment of an embassy in Sydney to protect the interests of Chinese residents. ${ }^{41}$ Xue Fucheng (1838-94) was assigned as imperial envoy (ambassador) to the United Kingdom, France, Italy and Belgium in the spring of 1889 . He considered Australia to be a part of Great Britain and included Wang's report about the Australian Chinese in his Diplomatic Journal of Four Countries (《出使英法义比四国日记》). He was also the author of an essay entitled 'On Independence of Australia' during his tenure, which showed his

\footnotetext{
38 Yong, The New Gold Mountain, 122.

39 Yong, The New Gold Mountain, 124.

40 苑书义、孙华峰、李秉新主编. 张之洞全集 (奏议). 石家庄 : 河北人民出版社, 1998: 401 [Shuyi Yuan, Huafeng Sun and Bingxin Li, eds, The Complete Works of Zhang Zhidong (Volume of Memorials to Emperor) (Shijiazhuang: Hebei Renmin Press, 1998), 401].

41 Yuan, Sun and Li, The Complete Works of Zhang Zhidong, 607.
} 
preference and confidence in Australia. He noted the differences between Australia and South-East Asia, and expressed his confidence that the Chinese would contribute effectively to the country's future.

\section{Conclusion}

As a national biography, the $A D B$ not only records the past but also reflects the present, with state working parties being allocated quotas on the basis of the current population when determining subjects of articles. The small numbers of Chinese people in the $A D B$ can be explained largely by virtue of their 'invisibility' in colonial Australia, but this invisibility is also indicative of the attitudes that partly led to the ideal of white Australia. In one sense, all the 'missing' people mentioned above, just to name a few, are important and valuable. Many of the Chinese men were prominent merchants, gardeners or farmers in regional Australia and significant contributors to their local communities, although they may not be 'famous' on a national scale. Should this disqualify the Chinese people and other non-Europeans groups from inclusion? What percentage should each ethnic group occupy? Who could be 'representative and famous'? All these questions are worthy of discussion. 
This text is taken from Australian Journal of Biography and History: No. 1, 2018, published 2018 by ANU Press, The Australian National University, Canberra, Australia.

doi.org/10.22459/AJBH.2018.09 